Pacific Journal of Mathematics

A NOTE ON ExpoNential L SUNS 


\section{A NOTE ON EXPONENTIAL SUMS}

\section{CARlitz}

Put $S(a)=\sum_{x, y \neq 0} e\left(x+y+a x^{1} y^{1}\right)$, where $x x^{1}=y y^{1}=1$, $e(x)=x+x^{2}+\cdots+x^{2^{n-1}}$ and the summation is over all nonzero $x, y$ in the finite field $G F(q), q=2^{n}$. Then it is shown that $S(\alpha)=0(q)$ for all $a \in G F(\alpha)$.

Let $p$ be a prime and put

$$
S_{2}(\alpha)=\sum_{x, y=1}^{p-1} e\left(x+y+a x^{\prime} y^{\prime}\right),
$$

where $e(x)=e^{2 \pi i x / p}$ and $x x^{\prime} \equiv y y^{\prime} \equiv 1(\bmod p)$. For $a=0$ it is evident that $S(0)=1$. Mordell [3] has conjectured that

$$
S_{2}(a)=0(p)
$$

for all $\alpha$. The writer [1] has proved that

$$
S_{2}(a)=0\left(p^{5 / 4}\right)
$$

for all $a$.

For the finite field $G F(q), q=p^{n}$, we may define

$$
S_{2}(a)=\sum_{x, y \neq 0} e\left(x+y+a x^{\prime} y^{\prime}\right),
$$

where $a \in G F(q)$,

$$
e(x)=e^{2 \pi i t(x) / p}, t(x)=x+x^{p}+\cdots+x^{p^{p-1}},
$$

$x x^{\prime}=y y^{\prime}=1$, and the summation is over all nonzero $x, y \in G F(q)$. We may conjecture that

$$
S_{2}(a)=0(q)
$$

for all $a \in G F(q)$.

In this note we show that (3) holds for $q=2^{n}$. Indeed if

$$
S_{1}(a)=\sum_{x \neq 0} e\left(x+a x^{\prime}\right),
$$

we show that, for $a \neq 0$,

$$
S_{1}^{2}(a)=q+S_{2}(a) \quad\left(q=2^{n}\right) .
$$

Since [2], [4]

$$
\text { , } S_{1}(a) \mid \leqq 2 q^{1 / 2},
$$


it is clear that (3) follows from (4) and (5). Indeed a little more can be said. Since, for $q=2^{n}, e(a)= \pm 1$, it follows that both $S_{1}(a)$ and $S_{2}(a)$ are rational integers and in fact nonzero. Hence (4) and (5) give

$$
-q<S_{2}(a) \leqq 3 q \text {. }
$$

2. To prove (4), we take

$$
\begin{aligned}
S_{1}^{2}(a) & =\sum_{x, y \neq 0} e\left[x+y+a\left(x^{\prime}+y^{\prime}\right)\right] \\
& =\sum_{x, y \neq 0} e\left[x+y+a(x+y) x^{\prime} y^{\prime}\right] .
\end{aligned}
$$

If we put

$$
u=x+y, v=x y
$$

then

$$
S_{1}^{2}(a)=\sum_{\substack{u, v \\ v \neq 0}} e\left(u+a u v^{\prime}\right) N(u, v)
$$

where $N(u, v)$ denotes the number of solutions $x, y$ of (7); since $v \neq 0$, $x$ and $y$ are automatically $\neq 0$.

For $u=0$, (7) reduces to $x^{2}=v$, so that $N(0, v)=1$ for all $v$. For $u \neq 0$, (7) is equivalent to

$$
x^{2}+u x=v .
$$

The condition for solvability of (9) is $t\left(u^{-2} v\right)=0$, where $t(x)$ is defined by (2). Hence the number of solutions of (9) is equal to $1+e\left(u^{-2} v\right)$, so that

$$
N(u, v)=1+e\left(u^{\prime 2} v\right) \quad(u v \neq 0) .
$$

Substituting from (10) in (8), we get

$$
\begin{aligned}
S_{1}^{(2)}(a) & =\sum_{v \neq 0} N(0,1)+\sum_{u, v \neq 0} e\left(u+a u v^{\prime}\right) N(u, v) \\
& =\sum_{v \neq 0} 1+\sum_{u, v \neq 0} e\left(u+a u v^{\prime}\right)\left\{1+e\left(u^{\prime 2} v\right)\right\} \\
& =q-1+\sum_{u, v \neq 0} e\left(u+a u v^{\prime}\right)+\sum_{u, v \neq 0} e\left(u+u^{\prime 2} v+a u v^{\prime}\right) .
\end{aligned}
$$

Since

$$
\sum_{u \neq 0} e(a u)=-1 \quad(a \neq 0),
$$

it follows, for $a \neq 0$, that

$$
S_{1}^{2}(a)=q+\sum_{u, v \neq 0} e\left(u+u^{\prime 2} v+a u v^{\prime}\right) .
$$

Replacing $v$ by $u^{2} v$, this becomes 


$$
\begin{aligned}
S_{1}^{2}(a) & =q+\sum_{u, v \neq 0} e\left(u+v+a u^{\prime} v^{\prime}\right) \\
& =q+S_{2}(a)
\end{aligned}
$$

so that we have proved (4).

3. We may define

$$
S_{3}(a)=\sum_{x, y, z \neq 0} e\left(x+y+z+a x^{\prime} y^{\prime} z^{\prime}\right) .
$$

The writer has been unable to find a relation like (4) involving $S_{3}(a)$.

\section{REFERENCES}

1. L. Carlitz, A note on multiple exponential sums, Pacific J. Math. $\mathbf{1 5}$ (1965), 757-765.

2. L. Carlitz and S. Uchiyama, Bounds for exponential sums, Duke Math. J. 24 (1957), 37-41.

3. L. J. Mordell, On a special polynomial congruence and exponential sum, Calcutta Mathematical Society Golden Jubilee Commemoration Volume, 1958/59, part 1, 29-32. 4. A. Weil, Some exponential sums, Proc. Nat. Acad. Sci. 34 (1949), 204-207.

Received June 17, 1968. Supported in part by NSF grant GP-5174.

DUKE UNIVERSITY

Durham, North Carolina 



\section{PACIFIC JOURNAL OF MATHEMATICS}

\section{EDITORS}

H. ROYDEN

Stanford University

Stanford, California

Richard Pierce

University of Washington

Seattle, Washington 98105
J. DugundJI

Department of Mathematics

University of Southern California

Los Angeles, California 90007

BASIL GORDON

University of California

Los Angeles, California 90024

\section{ASSOCIATE EDITORS}

E. F. BECKENBACH

B. H. NeUmanN

F. WOLF

K. YOSHIDA

\section{SUPPORTING INSTITUTIONS}

UNIVERSITY OF BRITISH COLUMBIA

CALIFORNIA INSTITUTE OF TECHNOLOGY

UNIVERSITY OF CALIFORNIA

MONTANA STATE UNIVERSITY

UNIVERSITY OF NEVADA

NEW MEXICO STATE UNIVERSITY

OREGON STATE UNIVERSITY

UNIVERSITY OF OREGON

OSAKA UNIVERSITY

UNIVERSITY OF SOUTHERN CALIFORNIA
STANFORD UNIVERSITY

UNIVERSITY OF TOKYO

UNIVERSITY OF UTAH

WASHINGTON STATE UNIVERSITY

UNIVERSITY OF WASHINGTON

$* * \quad * \quad *$
AMERICAN MATHEMATICAL SOCIETY
CHEVRON RESEARCH CORPORATION
TRW SYSTEMS
NAVAL WEAPONS CENTER




\section{Pacific Journal of Mathematics}

Vol. 30, No. $1 \quad$ September, 1969

William Wells Adams, Simultaneous diophantine approximations and cubic irrationals ..................................... 1

Heinz Bauer and Herbert Stanley Bear, Jr., The part metric in convex

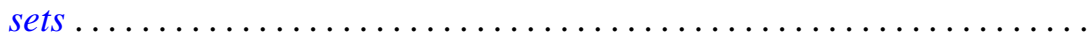

L. Carlitz, A note on exponential sums ...................... 35

Vasily Cateforis, On regular self-injective rings ................. 39

Franz Harpain and Maurice Sion, A representation theorem for measures on infinite dimensional spaces ......................... 47

Richard Earl Hodel, Sum theorems for topological spaces .............. 59

Carl Groos Jockusch, Jr. and Thomas Graham McLaughlin, Countable

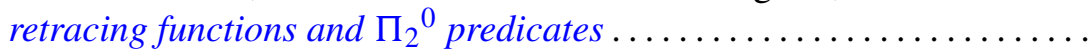

Bjarni Jónsson and George Stephen Monk, Representations of primary

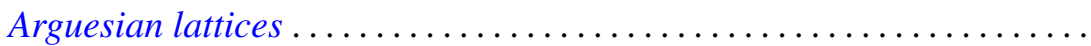

Virginia E. Walsh Knight, A continuous partial order for Peano continua...................................... 141

Kjeld Laursen, Ideal structure in generalized group algebras ........... 155

G. S. Monk, Desargues' law and the representation of primary lattices . . . 175

Hussain Sayid Nur, Singular perturbation of linear partial differential equation with constant coefficients ..........................

Richard Paul Osborne and J. L. Stern, Covering manifolds with cells ... 201

Keith Lowell Phillips and Mitchell Herbert Taibleson, Singular integrals in several variables over a local field...

James Reaves Smith, Local domains with topologically $T$-nilpotent radical....

Donald Platte Squier, Elliptic differential equations with discontinuous coefficients .................................

Tae-il Suh, Algebras formed by the Zorn vector matrix...

Earl J. Taft, Ideals in admissible algebras . .................... 259

Jun Tomiyama, On the tensor products of von Neumann algebras........ 263

David Bertram Wales, Uniqueness of the graph of a rank three group ..... 271

Charles Robert Warner and Robert James Whitley, A characterization of regular maximal ideals ......................... 